\title{
Organic Rice Supply Chain Strategy in Sawangan Organic Farmers Association, Magelang District, Indonesia
}

\author{
Ika Nurul Qamari, ${ }^{1, *}$, and Hammam Banu Ihsani $^{2}$ \\ ${ }^{1}$ Postgraduate Program, Universitas Muhammadiyah Yogyakarta, Indonesia \\ ${ }^{2}$ Department of Management, Universitas Muhammadiyah Yogakarta, Indonesia
}

\begin{abstract}
Indonesia is one of the countries that excel at organic agriculture. Exports to international markets are increasing from year to year. Organic agriculture is one of the farms in Indonesia that produces organic rice. Supply Chain Management (SCM) represents management science in agricultural activities that involve management, processing, distribution, marketing to products that consumers want. The research objectives: (1) identify supply chain actors and descriptive analysis of environmental conditions, (2) identify internal and external factors, (3) formulate strategies with a matrix of Strengths, Weaknesses, Opportunities, and Threats (SWOT), This study was carried out using a qualitative exploratory research approach, data were collected by interviewing ten people involved in the distribution of organic rice and secondary data. The results showed that the organic rice supply chain actors in Sawangan, Magelang District were farmers, Gapoktan, Gatos, and consumers. Based on the strategic formulation, five alternative strategies were obtained which consist of: (1) increasing the quality, quantity, and continuity of production, (2) expanding markets and facilitating distribution channels, (3) strengthening financial aspects, (4) conducting organic rice market research and planning. development, (5) facilitation and support from the government.
\end{abstract}

\section{Introduction}

Agriculture in Indonesia is a vital area for the Indonesian people's survival [1]. The Indonesian government's policy on Go Organic in 2010 became the attraction of Indonesian agriculture to switch to agriculture with an organic system. This is an opportunity for farmers in Indonesia, especially the Magelang area as one of the centers of rice production to change conventional farming patterns to quality organic farming. Efforts to increase income and meet national and international market opportunities require changes in production systems and supply chain institutions.

A supply chain is an entity consisting of individuals or groups that move products, services, finance, and information from sources to consumers in a continuous flow from

*Corresponding author: $\underline{\mathrm{ika} n \mathrm{nr} @ \text { umy.ac.id }}$ 
upstream to downstream [2]. To eliminate delays and inefficiencies, the supply chain is monitored continuously. One of the supply chains that must be maintained in order for the distribution system to run well is the food supply chain. Rice is an example of a food supply chain.

Organic farming is a type of environmentally friendly agriculture that use organic varieties, fertilizers, and pesticides with the goal of reducing negative environmental impacts and preserving the environment [3]. The Indonesian government's policy on Go Organic in 2010 became an attraction and opened up opportunities for farmers in Indonesia, especially the Magelang area as one of the centers of rice production to change conventional farming patterns to quality organic farming. This is a challenge to increase income and meet national and international market opportunities that require changes in production systems and supply chain institutions.

Designing a food agriculture industrialization system capable of producing food products with high added value for farmers, guaranteed food supply without any obstacles, controlled high quality, guaranteed product safety, and affordable food prices for the community is one of the efforts to improve the food security system. This can be accomplished by putting together a supply chain strategy that brings together actors from all supply chain segments, either vertically or horizontally [4]. The industrial agricultural system is characterized by high value-added agricultural businesses and integrated in a supply chain based on a synergistic and fair partnership relationship by relying on national resources, local wisdom, as well as environmentally sound science and technology. This study aims to present the right supply chain strategy for organic rice; what is the role of each stakeholder in the organic rice supply chain; and what factors determine the success of the organic rice supply chain.

\section{Literature Review}

\subsection{Supply chain strategy in the food industry}

The resilience of the food industry with sustainable development goals is an important priority scale because food consumption and trends and production patterns have high pressure on the environment, changes in the way food are produced, processed, transported, and consumed that must be taken into account to achieve sustainable development $[5,6]$. The Food and Agriculture Organization of the United Nations states that sustainable consumption and production in food and agriculture is a holistic consumer-driven concept that refers to the application of sustainable food consumption and production patterns, concerning the carrying capacity of natural resources and ecosystems.

A supply chain strategy is needed to help achieve the expected goals, especially in food distribution. Innovations in supply chain management strategic approaches will enable food companies or organizations to excel in competition [9]. Supply chain management strategic planning is needed as a source of decision making. A strategic perspective for sourcing from within and from outside the company aims to be able to compete based on product differentiation or focus. The elements of making a supply chain management strategy consist of 2 factors, namely primary factors (competitive advantage, demand flexibility) and secondary factors (process capability, timeout of the process, and strategic risk):

a. Primary Factor: 1) Competitive advantage can be obtained through product differentiation, cost pioneering (trying to minimize costs without reducing product value and quality), rapid response which is characterized by being flexible, reliable, and responsive to changes; 2) Demand Flexibility is affected by several factors: product, 
product mix, volume and type of delivery. Measurement and flexibility can be seen from the accuracy of delivery and accurate demand forecasting.

b. Secondary Factor: 1) The process capability factor is related to the extent to which the company can carry out the required activities and is highly dependent on the type of activity; 2) Timeout of the process factor is closely related to the level of process performance, how this process can be responsive and meet market offers; 3) Strategic risk includes the spread of risk, namely the risk that the company or organization receives due to leakage of information about its products and services, whether it is received or provided by suppliers so that competitors can know the company's strategies.

Supply chain strategy is a term used to describe the operational strategy in supply chain management. This strategy is defined as a set of strategic activities and actions implemented throughout the supply chain to reconcile what end customers require with the capabilities of existing supply chain resources [7]. Supply chain strategy leads to long-term planning for low-cost, high-quality, timely, and diverse products that help the supply chain meet its strategic objectives. This aim can be reached by having the company's ability to run efficiently, generate high-quality products, adapt swiftly to consumer needs, be flexible, and be innovative in responding to internal changes.

\subsection{Supply chain network}

The design of a company's supply chain network is a critical component of all operations. Companies will be able to manage their complete business network more easily with a supply chain network design since the information contained in the network design will be collected [8]. If a factor causes an error or damage, the organization makes immediate and exact changes to the supply chain network to avoid failure or loss [12].

Gatos, an association of farmers in Sawangan village, Magelang district, Indonesia, is the corporation or group that builds the supply chain network for an organic rice business. Farmers, organic farmers associations, organic product retailers, and consumers are all part of this supply chain. Three streams run through it: product flow, finance or money flow, and information flow.

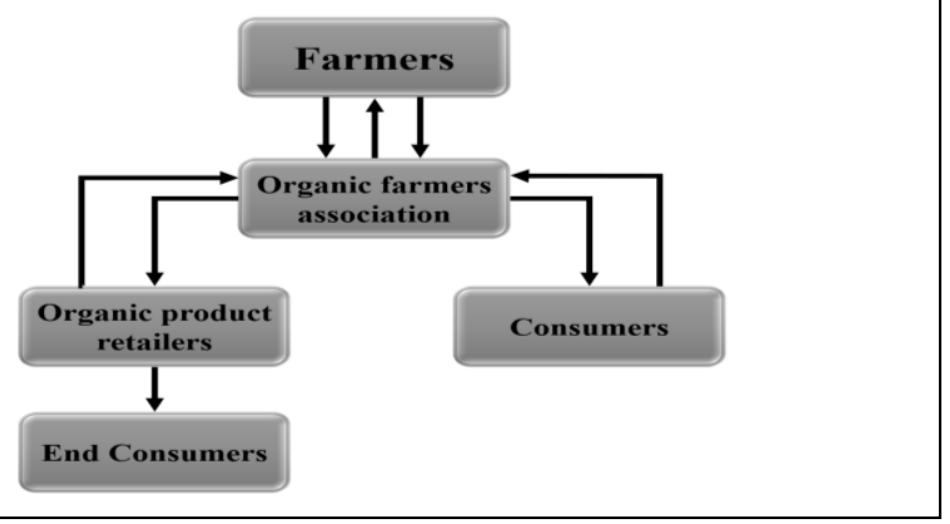

Fig. 1. Supply Chain Network in the organic rice business

Farmers are people who cultivate crops to produce organic rice at harvest time. Farmers in this organic rice supply chain network are active in cultivating organic rice into unhulled rice that is ready to be harvested and unhulled rice that is ready to be milled. Organic rice 
seeds are obtained from a combination of organic farmers who have provided organic rice seeds to be cultivated by farmers.

The Organic Farmers Association is an organization that acts as an intermediary between farmers and retailers of organic products and as an intermediary between farmers and final consumers. The task of the Organic Farmers Association is to buy ready-to-mill grain produced by farmers. The grain will go through several processes so that it becomes rice (after grinding). Rice after grinding will be selected again which has quality. Then the selected organic rice will be packaged in various packaging sizes. Because they interact directly with end-users in fulfilling and meeting their demands, organic product retailers play a critical role. For retailers, the primary goal of the supply chain is to meet and satisfy the needs of the end consumer.

The end consumer is the last organic rice supply chain and the final destination in the organic rice supply chain. End consumers in the organic rice supply chain are active in buying organic rice at organic product retailers or buying directly from organic farmers' associations. End consumers are very important because they provide information about the quality of organic rice purchased. The desired quality will be conveyed by final consumers to organic product retailers and organic farmer associations to farmers. End consumers also demand in addition to quality, namely speed and availability of goods at affordable prices, therefore all organic rice supply chain actors must work together and develop strategies to compete with other supply chains.

\subsection{Supply chain drivers}

The supply chain's driving factor is the factor that ultimately determines the chain's success. If the driving elements are met, the supply chain is considered successful. External and internal variables are the two types of supply chain management driving factors [13, 14]. Technological advancements, rising demand, maintaining reduced prices, and competition between corporations or organizations are all examples of external factors. Meanwhile, internal factors consist of increasing inventory turnover, increasing revenue, and decreasing costs.

The first stage in creating an effective supply chain is to guarantee that all supply chain players are working toward the same goals and are focused on meeting the demands of endusers. External factors and internal factors, which are the supply chain management's driving forces, must be examined and combined in each stage. Management can use risk mitigation measures to control risks or impediments that may occur, such as internal competition and managerial complexity.

\section{Methods}

\subsection{Sampling method and subjects}

A qualitative exploratory research approach with non-probability sampling is a requirement in this study, with the sampling technique is judgment sampling. This sampling is designed to acquire more relevant data that is only available to specific groups. According to Saunders, the sample sizes for in-depth interviews ranged from 5 to 25 [10]. Yin proposed that the sample size norm be at least 6 [11], which is consistent with this approach. Gatos managers make up five of the resource people from the farmer associations. Meanwhile, two retailers and three customers make up the buyer's group. As a result, there are ten total informants, which is a good quantity for qualitative research with in-depth interviews. 


\subsection{Procedures}

The first step is to identify the characteristics of potential rice products as organic rice products. Next, identify the actors in the rice supply chain at the Gatos organization and conduct a descriptive analysis of environmental conditions that affect organic rice production. The research was conducted at the center for producing organic rice products, Gatos (Sawangan Organic Farmers Association) in Sawangan village, Magelang district, Indonesia.

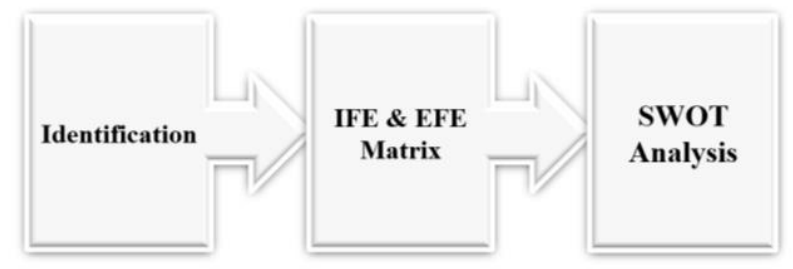

Fig. 2. Stages of Organic Rice Supply Chain Strategy

The next stage is described through the Internal Factor Evaluation (IFE) and External Factor Evaluation (EFE) matrices, then analyzed using the SWOT analysis to determine the position of Gatos in the competition for organic rice. The final stage is to provide alternative strategic decisions which are the result of SWOT mapping.

\subsection{Data Analysis}

The strategy formulation process in this study was carried out in three stages: 1) the input stage using the IFE and EFE matrices, 2) the matching stage using the Internal-External Factor Evaluation and 3) the decision stage to determine the best strategy selected using SWOT matrix

\section{Results and Discussion}

\subsection{General condition of Sawangan village}

Sawangan village is one of the sub-districts in Magelang. Sawangan is located between 110 degrees 34'681 east longitude and between 7 degrees 52'691 south latitude. The area of Sawangan is $70 \mathrm{~km}^{2}$ or $8.32 \%$ of the total area of the Magelang District. The total population of Sawangan is 55,351 people.

Sawangan is the area with the highest rainfall rate in Magelang Regency. The average annual rainfall in Sawangan village is 1,718-2,603 mm/year. In general, in the rainy season or the wet months, the monthly average rainfall is $161.6 \mathrm{~mm}$. While in the dry season the average rainfall is below $100 \mathrm{~mm}$. The air temperature ranges from 17-26 degrees. Water supply is sourced from the provision of groundwater and surface water. Surface water sources are concentrated in the Pabelan river, Kunjang river, and Krasak river. Groundwater sources in Sawangan are known to be numerous and abundant.

\subsection{Supply Chain Identification}

The supply chain is a series of productive activities that are interrelated with one another to form industrial value. The actors in the organic rice supply chain in the Sawangan subdistrict are farmers, Gapoktan (Farmers Group Association), Gatos (Sawangan Organic 
Farmers Association), and consumers. Each supply chain actor has its role. Farmers are actors who have a very important role, namely cultivating rice until it becomes ready-tomill grain. Gapoktan has a role as an intermediary between farmers and Gatos who is a producer of organic rice.

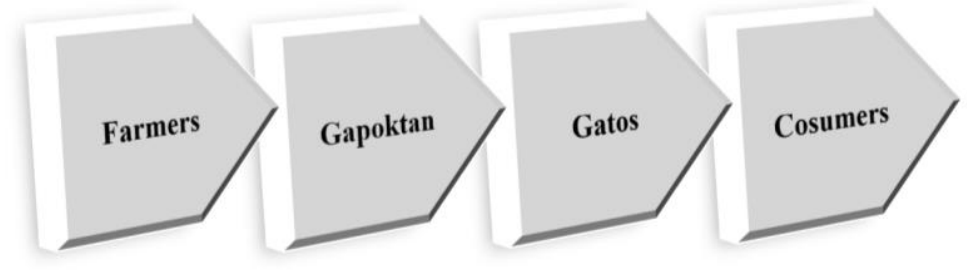

Fig. 3. Identification of organic rice supply chain in Sawangan

\subsection{Business Environment Analysis}

\subsubsection{Identify Internal Factors}

The internal environment is analyzed using a functional approach. Analysis was carried out on each function within the Gatos organization by reviewing management, marketing, finance, production, and operations. Based on the identification of internal factors, several strengths can be maximized to realize organic farming. Gatos is a place to strengthen cooperation between organic supply chain actors in improving the welfare of farmers in the face of several obstacles and threats. Good relations between organic rice supply chain actors are a force that can be utilized to achieve economies of scale, both in quality, quantity, and continuity of the products produced. Gatos has other strengths, namely organic rice that is produced in various ways, there are Mentik Wangi organic rice, IR64, organic brown rice, and organic black rice.

Table 1. Internal Factors in Gatos

\begin{tabular}{|l|l|}
\hline \multicolumn{1}{|c|}{ Strengths } & \multicolumn{1}{c|}{ Weaknesses } \\
\hline $\begin{array}{l}\text { A good relationship between the head of } \\
\text { Gatos and the members }\end{array}$ & $\begin{array}{l}\text { HR capabilities that have not been } \\
\text { maximized }\end{array}$ \\
\hline Rice is produced in a variety of ways & High organic production costs \\
\hline Very supportive geographical conditions & Weak access to markets \\
\hline $\begin{array}{l}\text { The rice products produced are of high } \\
\text { quality and safe for consumption }\end{array}$ & Limited capital \\
\hline Eco-friendly agriculture & $\begin{array}{l}\text { The price of organic rice with } \\
\text { conventional rice is almost the same }\end{array}$ \\
\hline
\end{tabular}

Organic rice comes in several varieties to satisfy the needs of consumers. The village of Sawangan is located at the foot of Mount Merapi and Merbabu, where the water is always running and the soil is fertile, making it ideal for agriculture. This is further aided by favorable geographical conditions, which allow for the production of high-quality, safe-toeat rice as well as environmentally responsible cultivation.

The weak points towards organic farming in Sawangan are the human resources capacity that is not maximized, the cost of producing organic rice is high (especially certification), while the price of organic rice and conventional rice is almost the same. Furthermore, weak access to markets due to limited distribution channels for organic products in Magelang District. Limited capital is also one of the weaknesses to develop 
organic rice [15]. Some of these weaknesses must be faced by organic rice supply chain actors in Sawangan District to get to the desired organic agriculture development.

\subsubsection{Identify External Factors}

Identification of external factors consists of opportunities and threats. The formulation of opportunities and threats can be taken into consideration for organic rice production strategies. External factors are identified by reviewing economic, socio-cultural, government, legal, demographic, and technology. Based on external factors, several opportunities were identified that could encourage the demand for organic rice to increase. These opportunities are the high selling price of organic rice, consumer loyalty, increasing population growth, changes in people's lifestyles that are back to nature, government support, and the 2010 Go Organic policy increased demand with a high selling price of organic rice. This will improve the welfare of the organic rice supply chain actors in Sawangan.

The results of external identification contained two threats, namely erratic weather and pest and disease attacks on plants. Threats can affect organic rice production and disrupt the organic rice supply chain. Supply chain actors must be able to prepare everything to deal with these threats.

Table 2. External Factors in Gatos

\begin{tabular}{|l|c|}
\hline \multicolumn{1}{|c|}{ Opportunities } & \multicolumn{1}{|c|}{ Threats } \\
\hline The selling price of organic rice is higher & Uncertain whether affects production \\
\hline High consumer loyalty & Pests and diseases attack plants \\
\hline Increasing population growth & - \\
\hline $\begin{array}{l}\text { People's lifestyles and consumption patterns } \\
\text { tend to return to nature }\end{array}$ & - \\
\hline $\begin{array}{l}\text { Government support and policy on Go } \\
\text { Organic 2010 }\end{array}$ & - \\
\hline
\end{tabular}

\subsubsection{IFE matrix analysis}

Table 3. IFE Matrix Analysis

\begin{tabular}{|c|c|c|c|}
\hline Strengths & $\begin{array}{c}\text { Weight } \\
\text { (W) }\end{array}$ & $\begin{array}{l}\text { Rating } \\
\text { (R) }\end{array}$ & $\mathbf{W} \times \mathbf{R}$ \\
\hline A good relationship between the head of Gatos and the members & 0.14 & 3.70 & 0.51 \\
\hline Rice is produced in a variety of ways & 0.14 & 3.70 & 0.51 \\
\hline Very supportive geographical conditions & 0.14 & 3.80 & 0.53 \\
\hline $\begin{array}{l}\text { The rice products produced are of high quality and safe for } \\
\text { consumption }\end{array}$ & 0.14 & 3.90 & 0.56 \\
\hline Eco-friendly agriculture & 0.13 & 3.40 & 0.43 \\
\hline Tot a l & 0.69 & & 2.54 \\
\hline Weaknesses & $\begin{array}{c}\text { Weight } \\
\text { (W) }\end{array}$ & $\begin{array}{c}\text { Rating } \\
\text { (R) }\end{array}$ & $\mathbf{W} \times \mathbf{R}$ \\
\hline HR capabilities that have not been maximized & 0.06 & 1.60 & 0.09 \\
\hline High organic production costs & 0.07 & 1.80 & 0.12 \\
\hline Weak access to markets & 0.07 & 1.80 & 0.12 \\
\hline Limited capital & 0.06 & 1.50 & 0.08 \\
\hline The price of organic rice with conventional rice is almost the same & 0.07 & 1.80 & 0.12 \\
\hline Tot a l & 0.31 & & 0.54 \\
\hline Total amount & 1 & & 3.08 \\
\hline
\end{tabular}

The results of the analysis of internal factors identified several things that became the strengths and weaknesses of GATOS. Determination of weights and ratings on the 
questionnaires involved several parties, including Head of Gatos, General Affairs Division of Gatos, Gatos Product Processing Division, Information Technology Division of Gatos, Marketing Division of Gatos, and 5 consumers.

Assessment of internal factors obtained a total score of 3,08. The score shows that Gatos' ability to take advantage of opportunities and overcome weaknesses is quite strong. The results of the IFE matrix can be concluded that the quality and safe organic rice products produced are the main strengths with a score of 0,56 . Thus, a quality and safe organic rice production system is the main step towards better organic farming [16-18]. Meanwhile, three weaknesses have the highest and the same score. The weaknesses in question are high production costs, weak access to markets, the price of organic rice with conventional rice is almost the same. These three weaknesses have a score of 0,12 .

\subsubsection{EFE matrix analysis}

The EFE Matrix is a matrix that contains the opportunities and threats faced by Gatos. Opportunities and threats are obtained from the identification process of the external environment. Giving weights and ratings to the EFE matrix is the same as giving weights and ratings to the IFE matrix. The assessment of the EFE matrix in Table 4 obtained a total score of 3.34. These results mean that Gatos' ability to take advantage of existing opportunities and overcome the threats faced is quite strong. The biggest opportunity to go organic farming is the government policy on Go Organic 2010 with a score of 0.58 . The biggest threats faced are pests and diseases of rice with a score of 0.15 .

\subsubsection{Internal-External Matrix}

The results of internal and external evaluation and analysis produce an IE Matrix (Figure 4) to determine the current position of Gatos. The selection of alternative strategies in the face of competition can be determined by mapping the company's position. The IFE matrix value is 3.08 and the EFE matrix is 3.34 which can indicate that Gatos' position is in Quadrant I (Grow and Build). The right strategy is carried out by Gatos, namely market penetration, market development, and product development

Table 4. EFE Matrix Analysis

\begin{tabular}{|l|r|r|r|}
\hline \multicolumn{1}{|c|}{ Opportunities } & \multicolumn{1}{c|}{$\begin{array}{c}\text { Weight } \\
\text { (W) }\end{array}$} & $\begin{array}{c}\text { Rating } \\
\text { (R) }\end{array}$ & W x R \\
\hline The selling price of organic rice is higher & 0.15 & 3.70 & 0.55 \\
\hline High consumer loyalty & 0.15 & 3.70 & 0.55 \\
\hline Increasing population growth & 0.14 & 3.60 & 0.52 \\
\hline $\begin{array}{l}\text { People's lifestyles and consumption patterns tend to return to } \\
\text { nature }\end{array}$ & 0.13 & 3.30 & 0.44 \\
\hline Government support & 0.14 & 3.40 & 0.46 \\
\hline Government policy on Go Organic 2010 & 0.15 & 3.80 & 0.58 \\
\hline T o t a I & $\mathbf{0 . 8 6}$ & & $\mathbf{3 . 1 0}$ \\
\hline Threats & $\begin{array}{c}\text { Weight } \\
\text { (W) }\end{array}$ & $\begin{array}{c}\text { Rating } \\
\text { (R) }\end{array}$ & W x R \\
\hline Uncertain whether affects production & 0.07 & 1.70 & 0.12 \\
\hline Pests and diseases attack on plants & 0.08 & 1.90 & 0.15 \\
\hline T o t a I & $\mathbf{0 . 1 4}$ & & $\mathbf{0 . 2 7}$ \\
\hline Total amount & 1 & & 3.34 \\
\hline
\end{tabular}




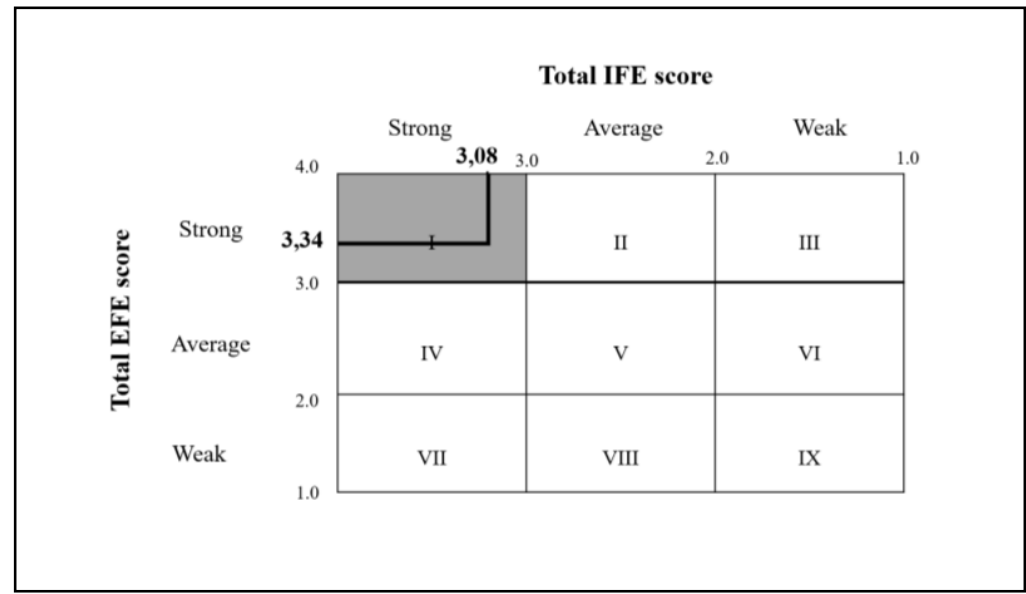

Fig. 4. Internal-External Matrix Analysis

\subsubsection{SWOT Matrix Analysis}

The SWOT matrix aims to produce the right strategic alternatives. Not all alternative strategies developed in the SWOT matrix will be selected and implemented. With this SWOT analysis, Gatos can develop an appropriate competitive strategy based on a combination of internal and external factors that have been presented in the IFE and EFE matrices, thus creating an appropriate strategy based on Gatos' position and condition. With the right strategic choice, it is expected to be able to take advantage of strengths and opportunities to reduce weaknesses and face existing threats.

\begin{tabular}{|c|c|c|}
\hline External Factors & $\begin{array}{l}\text { Strenghts } \\
\text { 1. Good relationship between the head of } \\
\text { Gatos and the members } \\
\text { 2. Variety of rice produced } \\
\text { 3. Very supportive geographical conditions } \\
\text { 4. The rice products produced are of high } \\
\text { quality and safe for consumption } \\
\text { 5. Eco-friendly agriculture }\end{array}$ & $\begin{array}{l}\text { Weaknesses } \\
\text { 1. HR capabilities that have not been } \\
\text { maximized } \\
\text { 2. High organic production costs } \\
\text { 3. Weak access to markets } \\
\text { 4. The price of organic rice with } \\
\text { conventional rice is almost the same } \\
\text { 5. Limited capital }\end{array}$ \\
\hline $\begin{array}{l}\text { Opportunities } \\
\text { 1. The selling price of organic rice is high } \\
\text { 2. High consumer loyaltyI } \\
\text { 3. ncreasing population growth } \\
\text { 4. Changes in people's lifestyles and } \\
\text { consumption patterns tend to return to } \\
\text { nature } \\
\text { 5. Government support } \\
\text { 6. There is a government policy on Go } \\
\text { Organic } 2010\end{array}$ & $\begin{array}{l}\text { SO Strategy } \\
\text { 1. Improving the quality, quantity and } \\
\text { continuity of production } \\
\text { 2. Premium organic rice product } \\
\text { development } \\
\text { 3. Expanding the market and simplifying } \\
\text { distribution channels }\end{array}$ & $\begin{array}{l}\text { WO Strategy } \\
\text { 1. Meet the quality standards of organic } \\
\text { rice products according to the wishes } \\
\text { of the buyer } \\
\text { 2. Establish partnerships with } \\
\text { supermarkets in the distribution of } \\
\text { organic rice products } \\
\text { 3. Government facilitation and support } \\
\text { 4. Strengthening the financial aspect } \\
\text { (capital) }\end{array}$ \\
\hline $\begin{array}{l}\text { Threats } \\
\text { 1. Uncertain weather affects production } \\
\text { 2. Pests and diseases attack on plants }\end{array}$ & $\begin{array}{l}\text { ST Strategy } \\
\text { 1. Planning better planting methods } \\
\text { 2. Superior organic rice product } \\
\text { development }\end{array}$ & $\begin{array}{l}\text { WT Strategy } \\
\text { Conduct organic rice market research } \\
\text { and development planning }\end{array}$ \\
\hline
\end{tabular}

Fig. 4. SWOT Analysis 


\section{Conclusion and Managerial Implications}

\subsection{Conclusion}

The organic rice supply chain in Sawangan consists of farmers, Gapoktan, Gatos, and consumers. Gatos cooperates with farmers by providing free seeds, then when harvesting the farmers sell to Gatos by collecting their crops in Gapoktan. Gatos will take the harvest and then process it into organic rice, then package in various packages and products that are ready to be sold to consumers.

The IFE and EFE matrices demonstrate that the main strength is the quality of the rice product produced, which is also safe to eat. The three most significant limitations are the high cost of organic cultivation, limited market access, and the price of organic rice is nearly identical to conventional rice. The primary opportunity is the government's Go Organic 2010 strategy. Plant pests and diseases are the most serious hazard.

The results of the formulation obtained 5 recommended strategies. The main strategic priority is to improve the quality, quantity, and continuity of production. The second priority is expanding the market and simplifying distribution channels. The third priority is to strengthen the financial aspect (capital). The fourth priority is conducting market research for organic rice and development planning. The last priority is government facilitation and support.

\subsection{Managerial Implications}

The results of the SWOT analyses indicate that improving the quality, quantity, and consistency of organic rice products is the best alternative option. Maintaining manufacturing processes ranging from nurseries to ready-to-sell products, as well as conducting quality control on the organic rice products produced helps to improve the quality of organic rice products. Quality control is a strategy for increasing customer satisfaction by selecting the highest-quality organic rice. Improving work procedures and enhancing agricultural production are two ways to increase product amount. Consumer demand for organic rice products can be addressed if the amount of organic rice products is increased. Increased product consistency is achieved by enhancing the structure of the organic rice supply chain, making the production process more efficient and sustainable to maximize profit.

\section{References}

1. Handayani, Sri, and Muhammad Irfan Affandi. Supply Chain Management Performance Of Organic Rice In Pringsewu Regency. Journal of International Conference Proceedings (JICP). 2, 1 (2019).

2. Mukhamedjanova, Kamola A. Concept of supply chain management. Journal of Critical Reviews. 7, 2 (2020). https://doi.org/10.31838/jcr.07.02.139.

3. Willer, Helga, Julia Lernoud, and Laura Kemper. The world of organic agriculture 2018: Summary. The World of Organic Agriculture. Statistics and Emerging Trends 2018. Research Institute of Organic Agriculture FiBL and IFOAM-Organics International, pp. 22-31 (2018).

4. Purwandoko, Pradeka Brilyan, and Kudang Boro Seminar. Design Framework of a Traceability System for the Rice Agroindustry Supply Chain in West Java. Information 10, 6, pp. 218 (2019). 
5. FAO (Food and Agricultural Organisation), Food wastage footprint \& climate change: food and agricultural organisation of United Nations (2015), available at: www.fao.org/ 3/a-bb144e.pdf.

6. Govindan, Kannan. Sustainable consumption and production in the food supply chain: A conceptual framework. International Journal of Production Economics, 195, pp. 419431 (2018). https://doi.org/10.1016/j.ijpe.2017.03.003.

7. Tan, Keah Choon. A framework of supply chain management literature. European Journal of Purchasing \& Supply Management, 7, 1, pp. 39-48 (2001). https://doi.org/10.1016/S0969-7012(00)00020-4.

8. Jouzdani, Javid, and Kannan Govindan. On the sustainable perishable food supply chain network design: A dairy products case to achieve sustainable development goals. Journal of Cleaner Production, 278, (2021).

https://doi.org/10.1016/j.jclepro.2020.123060.

9. Islam, Azmi Muhammad, and Ika Nurul Qamari. Effect of Supply Chain Management on Competitive Advantage and Organizational Performance. Studies on the Batik Industry in Yogyakarta City. 4th International Conference on Sustainable Innovation 2020-Accounting and Management (ICoSIAMS 2020). Atlantis Press, (2021).

https://doi.org/10.2991/aer.k.210121.047.

10. Saunders, Mark NK, and Frank Bezzina. Reflections on conceptions of research methodology among management academics. European management journal, 33, 5 pp. 297-304 (2015). https://doi.org/10.1016/j.emj.2015.06.002.

11. R.K. Yin, Case Study Research Design and Methods, 5th edition, SAGE Publications, California, (2014).

12. Prasertwattanakul, Y., and P. Ongkunaruk. The analysis of a vertically integrated organic rice company: a case study in Thailand. International Food Research Journal, 25, 2, pp. 481-486 (2018).

13. Zimon, Domnik, Jonah Tyan, and Robert Sroufe. Drivers of sustainable supply chain management: Practices to alignment with un sustainable development goals. International Journal for Quality Research, 14, 1, pp.219-236 (2020).

14. Setiawati, A., M. Wijaya, and R. Setyowati. The Role of the Sawangan Organic Rice Farmers Association in Increasing the Economic Value of Organic Rice: Case Study in Sawangan, Magelang. IOP Conference Series: Earth and Environmental Science. 715, 1, IOP Publishing, 2021.

15. Z. Rozaki, Indardi, Triyono, I. Salassa, and R. B. Nugroho. Farmers' responses to organic rice farming in Indonesia: Findings from central Java and south Sulawesi. Open Agric. 2020, 5, 703-710.

16. Z. Rozaki, O. Wijaya, and C. K. Wardana. Agriculture developement based on regional potency in kulonprogro regency. IOP Conf. Ser. Earth Environ. Sci. 2021, 683.

17. Triyono, N. Rahmawati, and Z. Rozaki. Sustainable value of rice farm based on economic efficiency in Yogyakarta, Indonesia. Open Agric. 2021, 6, 563-572.

18. Winarno, B. Neoliberal Policy of Indonesia's Agricultural Revitalization. Jurnal Hubungan Internasional. 2016, 5, 31-39. 